\title{
EFFECT OF DIETARY SUGAR BEET PULP AND ENZYMES ON SOME PHYSIOLOGICAL PERFORMANCE OF GROWING RABBITS
}

\author{
A.Kh. Abdel-Moty Abd El-Ghani, B.E. Soliman and Aya S.A. Abd El-Latif \\ Department of Animal and Poultry Production, Faculty of Agriculture, Minia University, Minia, Egypt
}

A total number of 36 males, 8 weeks old growing New Zealand White (NZW) rabbits used in this study. Rabbits were randomly distributed into 6 treatments, each one contains 6 males. Three levels of sugar beet pulp (SBP) and two levels of enzymes preparation were used in a $3 \times 2$ factorial arrangement. Sugar beet pulp were used at levels of 0 (control), 50 and $100 \%$ of the diets. Enzymes preparation was added a $t 0$ and $500 \mathrm{~g} /$ ton of diet. At the end of experimental period blood samples were collected from 3 rabbits of each treated groups were chosen, two blood samples were immediately collected from each rabbit. The first sample was collected in heparinized tube $(2.25 \mu$ heparin / $5 \mathrm{ml}$ blood) for studying the blood picture. The second sample was collected in nonheparinized tube and centrifuged for 5 minutes at 10000 R.P.M to separate, serum, for studying some blood metabolites parameters. Obtained results showed that, Rabbits fed control diet recorded an increasing $(\mathrm{P}<0.05)$ in corpuscular hemoglobin concentration $(\mathrm{MCHC})$ values compared with rabbits fed $100 \%$ SPB in their diet. Adding enzyme to rabbit diets reduced $(\mathrm{P}<0.05)$ the values of the packed cell volume (PCV) and hemoglobin ( $\mathrm{HB} \%$ ) compared to the control diet. The greatest slightly numerically improvement in the values of Red blood cells (RBC's), white blood cells (WBC`s), PCV, and mean corpuscular hemoglobin (MCH) was for rabbits fed dietary $100 \%$ SBPwithout enzyme addition compared with other dietary treatments. Rabbits fed dietary $100 \%$ SBP and incorporated with enzyme recorded the greatest $(\mathrm{p}<0.05)$ value of glucose and triglycerides followed by others fed dietary 50\% SBP and incorporated with enzyme compared with all dietary contain either SBP or encroporated with or without enzyme (SBP $\times$ enzyme). The greatest $(\mathrm{P}<0.05)$ enhancement in the values of AST and AST / ALT ratio was recorded for rabbit fed dietary enzyme compared with the control diet.

Keywords: sugar beet pulp, blood parameters, enzymes, growing NZW rabbits 